The Global Circulation of the Atmosphere 



\section{THE GLOBAL CIRCULATION OF THE ATMOSPHERE}

Edited by

Tapio Schneider

and Adam H. Sobel

Foreword by

Edward N. Lorenz

PRINCETON UNIVERSITY PRESS I PRINCETON AND OXFORD 
Copyright (C) 2007 by Princeton University Press

Published by Princeton University Press, 41 William Street,

Princeton, New Jersey 08540

In the United Kingdom: Princeton University Press, 3 Market Place,

Woodstock, Oxfordshire OX20 1SY

All Rights Reserved

Library of Congress Cataloging-in-Publication Data

The Global circulation of the atmosphere/edited by Tapio Schneider and Adam H. Sobel; foreword by Edward Lorenz.

p.cm.

Includes bibliographical references and index.

ISBN-13: 978-0-691-12181-9 (cloth: alk.paper)

1. Atmospheric circulation. I. Schneider, Tapio, 1972-II. Sobel, Adam H., 1967-

QC880.4.A8G572 2007

551.51'7-dc22 2006049293

British Library Cataloging-in-Publication Data is available

This book has been composed in Minion and Univers

Printed on acid-free paper.

pup.princeton.edu

Printed in the United States of America

$\begin{array}{llllllllll}10 & 9 & 8 & 7 & 6 & 5 & 4 & 3 & 2 & 1\end{array}$ 